\title{
SYNTACTIC COMPETENCE OF TRANSFORMATION IN EMBEDDED SENTENCES OF SPOKEN BAHASA INDONESIA OF JUNIOR HIGH SCHOOL STUDENTS
}

\author{
Ida Nur'aeni, Suparno, Titik Harsiati, Sumadi \\ Doctoral Program of Letters Faculty of Universitas Negeri Malang, Indonesia \\ Jalan Semarang 5 Malang, East Java, Indonesia \\ Corresponding Author: neng941@yahoo.com
}

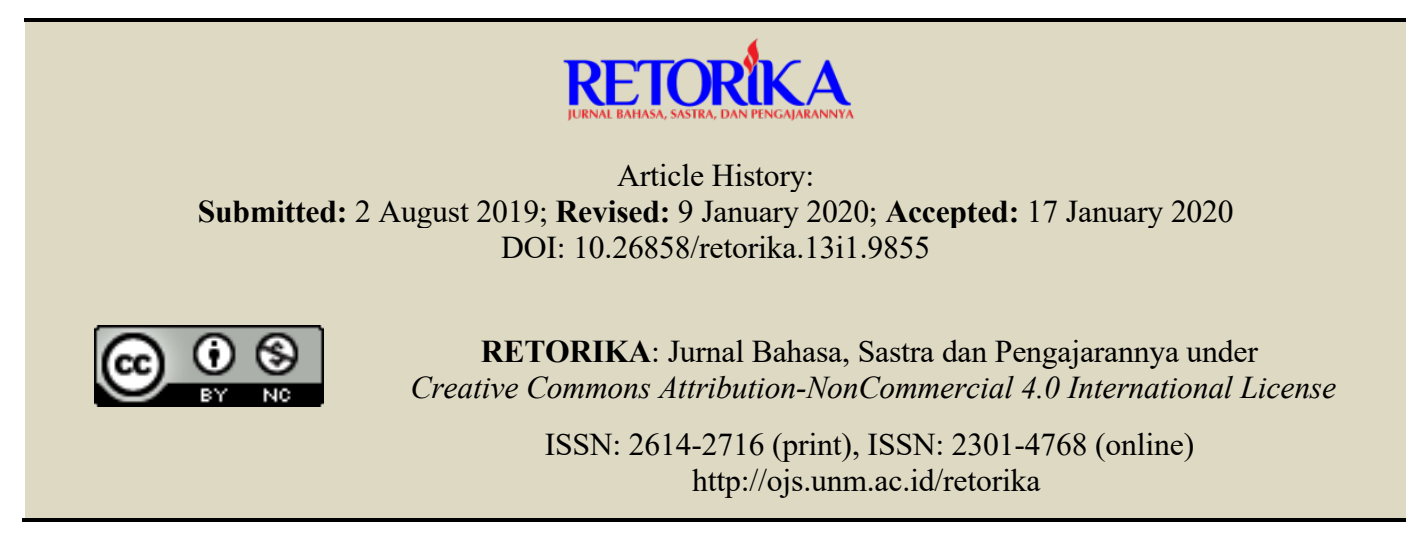

\begin{abstract}
The purpose of this study was to describe the process of transformation and complexity of embedded sentences. This type of research is a one-site case study. The data source of this study was the verbal text of the students' utterances. The data, in the form of accepted sentences, were analyzed by using the interactive model of Milles \& Huberman. The results shows that the transformation process in junior high school students' embedded sentences of spoken Bahasa Indonesia were included the use of TTF, TTKLesap, TTNom, TTGanKlit, TSA, TSPelFN, and TSPelFV rules. The complexity of students' sentence is shown by the use of the seven rules of transformation in a sentence. This finding shows that the eighth grade students have syntactic competence in the transformation of embedded sentences.
\end{abstract}

Keywords: syntactic competence, embedded transformation sentence, spoken language

Syntactic competence of spoken Bahasa Indonesia of the eighth grade middle school students in embedded sentences was the competence of students in making complex sentences. This competence is still abstract and can be seen or appears when it has been uttered. It comes from the language tool, which is a device that Chomsky (1965) calls a language acquisitioin device (LAD).

Based on the theory of language development, the eighth grade students' syntactic com- petence shows students' ability to produce the language in formal operational periods. This period indicates that students have been able to produce speech which is generally characterized by the uniqueness of both the lexical and grammatical aspects. Short and new forms often appear in formal and non-formal speeches as well.

Syntactic competence plays an important role in the success of language learning, both in spoken language learning through speaking (Wahyuni, et al. 2014; del Castillo, 2016) and 
listening, as well as in written language learning through reading (Cain: 2007) and writing (Rahmalia: 2016). Suwarno (2017) revealed that students' spoken language proficiency (oral) is a key component of the success of language learning (foreign languages). Spoken language research becomes important because researching spoken language features is the right way to get a picture of students' syntactic competence and can be applied in language learning in the classroom.

One of the forms of syntactic competence in students 'oral language is the students' competency in composing embedded sentences. The embedded sentence is a transformation sentence which is one of the special languages of junior high school students' spoken language. Through embedded sentences, junior high school students can convey their ideas vary. Variation in embedded sentences is a form of student creativity in processing and conveying information. The embed sentence is one of the uses of scientific language because it has the characteristic of information density which is shown by some information that is presented simultaneously.

Samsuri (1991: 307) defines embedded sentence as a transformational sentence by inserting one sentence into another one as part of it. The embedded sentence has three characterristics. The first characteristic is the completing clauses that are used to complete and explain the parts that are considered important. The second characteristic is that the sentence consists of at least two basic sentences, one of which is pinned to the other. The third characeristic is the sentence consists of matrix sentence and integrating sentence. The number of matrix sentences is only one and is clarified by one or several sentences of the integrators (Samsuri, 1985: 301; Samsuri, 1994: 307), Suhardi (2009) calling it the complement clause.

The composer of embedded sentence is the basic sentence. These basic sentences become matrix sentences and integrating sentences. The basic sentence in Indonesian consists of five patterns, namely FN1 + FN2 (KD1), FN + FV (KD2), FN + FA (KD3), FV + FNum (KD4), and FN + FPrep (KD5).

The embedded sentence is divided into five types based on the embedding marker. In Bahasa Indonesia sentences, the embedding markers are yang, bahwa, and untuk. The transformed sentence is shown by the use of the attributes, complementary FN, complementary FV, complementary FA, and complementary FNum/FP.

Attributive embedding sentences are basic sentences that are integrated in complex sentences, in which the subject turns into yang particles. Suparno (1993: 156) states that syntacticly, the construction of yang is an attribute to nouns or nominal phrases. The construction of yang occurs because nouns or nominal phrases are not present. The construction of yang can be present in six patterns, namely yang $+\mathrm{FN}$, yang $+\mathrm{FV}$, yang + FA, yang + FNum, yang + FPrep, and yang + Konj.

The embedded sentence complemented by FN. The FN complement is obtained from the embedding sentences marked by particle of bah$w a$ and definitive particle of itu. The embedder of bahwa with complementary or noun clause changes its character to a nominal phrase. This can be proven by a single transformation of object-focused or passivity. The object placement to the front of the sentence causes the change from verb shape of $\left({ }_{\operatorname{me}(\mathrm{N})}\right)$ to $\mathrm{V}$ with prefix (di-) (Samsuri, 1985: 312).

The embedded sentence with complement $\mathrm{FV}$ is an embedded sentence which adverbing the FV. The sentence with FV complement is marked by the embidder untuk. As FV consists of transitive and intransitive Vs, the rule that states the complementary embedding process of $\mathrm{FV}$ is divided into two. First, in the intransitive matrix sentence, the subject must be the same as the integrating clause subject. Second, in the transitive matrix sentence, the object must be the same as the subject of the integrating clause (Samsuri, 1985: 314).

The embedded sentence with FA complement is the embedded sentence that adverbing the FA. The sentence complemented by FA is marked by the embidder untuk. Samsuri (1994: 314) states that the sentences embedded in other sentences that use FA as the predicate, then the embedded marker is apa. The use of both FA embedders must be payed attention to the similarity of the integrating subject to the matrix subject. If the subjects arethe same, then the embedder used is untuk. If the subject is different from the sentence matrix and the integrating sentence, then the embedder used is apa.

The embedder for FNum and FPrep complements is untuk. Both types of phrases show the same symptoms in forming their complements. Both complementary phrases have only one 
complement: FN + FV. The requirement for using the embedder untuk is that the subject in the sentence matrix and the integrating sentence are the same.

Lapoliwa (1990:73-257) divides embedded sentence into two categories: declarative and nondeclarative embedded sentences. Declarative embedded sentences are the sentences embedded in the form of neither interrogative nor imperative. Nondeclarative embedded sentences are the embedded interrogative or imperative sentences.

Previous research related to the embedded sentence was conducted by Shofiyuddin (2013). The focus of the research was the embedded sentences in the translation of al-Quran. The results of the study indicated that there are 4 transformations types of embedded sentence, namely relative clauses, FN subtitutes, FV subtitutes, and FA substitutes.

Previous studies relating to embedded sentences were also carried out by Pancarrani (2018). The results of the study entitled "The Complexity of Indonesian Sentences of Class IV-VI Elementary School Students" showed that students in grades IV through VI of elementary school had mastered single sentences, embedded sentences, and closed sentences. In the embedded sentence, students use the pin and for. That pinned also appeared, but on a small frequency.

The syntactic competency research in the verbal embed Indonesian sentence of 8th-grade students of junior high school needs to be done to map the syntactic competence of students in composing sentences using the patterns of transformation rules. Besides, this research is also needed to describe the process of forming embedded transformation sentences.

\section{METHOD}

This research uses a qualitative approach. The type of qualitative research chosen was a one-site case study. This research site is in SMPN 1 Palu with the case of a group of students as speakers of Indonesian as Mother's tongue. The data source of this research is the oral text of 8th-grade students of SMPN 1 Palu, amounting to 22 students. When collecting data, the researcher engages the teacher and approaches psychologically with students. This is done to avoid bias caused by the presence of researchers. Data collection techniques in this study were observation, recording techniques, and interview techniques. Observation techniques are carried out in schools, both during learning and outside of learning. The recording is done using a special voice recorder (voice recorder). The selected interview is an open interview.The data of this research was in form of accepted sentences.

This research data is in the form of received sentences. Data analysis uses the interacttive method of Milles \& Huberman (1984:10) which consists of 3 stages, namely (1) data reduction including identification, grouping, and coding of data; (2) data presentation based on transformation theory; and (3) concluding. The validity of the research results is validated by prolonging the research period, research perseverance, and triangulation. Triangulation is carried out using data sources and data collection techniques.

\section{FINDINGS AND DISCUSSION}

\section{Findings}

Based on the results of the study, the syntactic competence of spoken Bahasa Indonesia of the eighth grade students of SMPN 1 Palu, which was shown in transformation of embedded sentences, is discussed continuously. The results of the study are presented following this flow: each sentence is described based on the pattern of basic sentences that form the embedded sentence, then the process description of transformation of the embedded sentence, and the pattern of the embedded sentence.

\section{Attributive Embedded Sentence}

Based on the results of the study, the syntactic competence of spoken Bahasa Indonesia of the eighth grade students of SMPN 1 Palu, which was shown in the embedded sentences, had an attributive pattern. Students' syntactic competence of spoken Bahasa Indonesia which has the attributive pattern is explained in the following sentence (1).

(1) Kamar yang dibuatnya dengan nuansa $u$ lang tahun.

Sentence (1) is included in embedded transformation sentence with embedder yang. 
This sentence has the KD5 matrix pattern, which is Kamar dengan nuansa ulang tahun. The sentence also has the integrating sentence (SSO) of membuat kamar. This integrating sentence (KP) provides information (attributive) on the $\mathrm{FN}$, which is kamar. The following is the basic structure analysis (SD) and the transformation structure (ST) of the sentence.

KM: Kamar dengan nuansa ulang tahun.

SD (KD5): FN + FPrep

KP: (SSO) membuat kamar.

$\mathrm{SD}(\mathrm{KD} 2): \mathrm{FN} 1+\mathrm{FV}+\mathrm{FN} 2$

$\mathrm{KP}^{1}$ Kamar dibuat $(\mathrm{SSO})$

TTNom: Transformasi Tunggal Nominalisasi

(Nominalisation Single Transformation)
$\mathrm{STP}^{1}$ (TTF): FN2 + FV + FN1

$\mathrm{KP}^{2}$ : Kamar dibuatnya.

$\mathrm{ST}^{2}$ : (TTGanKlit): FN2 + FV+klitika

KS: Kamar yang dibuatnya dengan nuansa ulang tahun.

ST: $\quad \mathrm{FN}+\mathrm{KP}^{2}+$ Fprep

Description:

SSO: Seseorang (Someone)

TTF: Transfromasi Tunggal Fokus (Focused Single Transformation)

TTGanKlit: Transformasi Tunggal Penggantian

Klitika (Klitika Subtitute Single Transformation)

The process of sentence (1) transformation is described in the following chart.

KM : Kamar dengan nuansa ulang tahun.

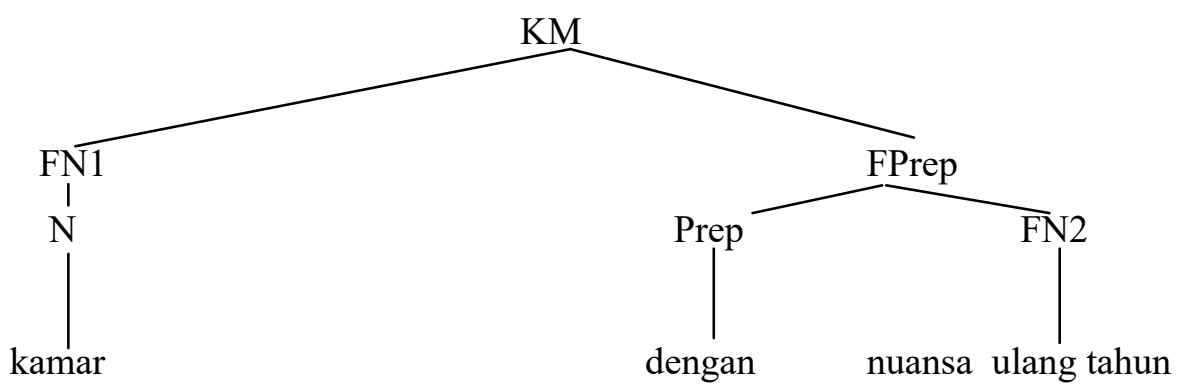

The above matrix sentence is the basic KD5 pattern, which is FN + FPrep.

$\mathrm{KP}=(\mathrm{SSO})$ membuat kamar.

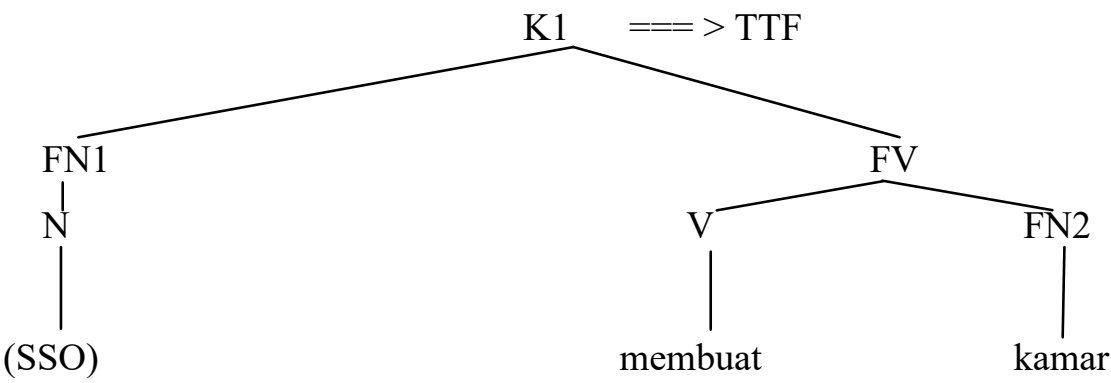

The above integrating sentence is in the form of a basic KD2 pattern, namely FN + FV. The basic sentence undergoes a focused single transforma-

tion with the transfer pattern (TTFPindah). The moved part of the sentence is FN2, which is kamar.

$\mathrm{KP}^{1}=$ Kamar dibuat $(\mathrm{SSO})$.

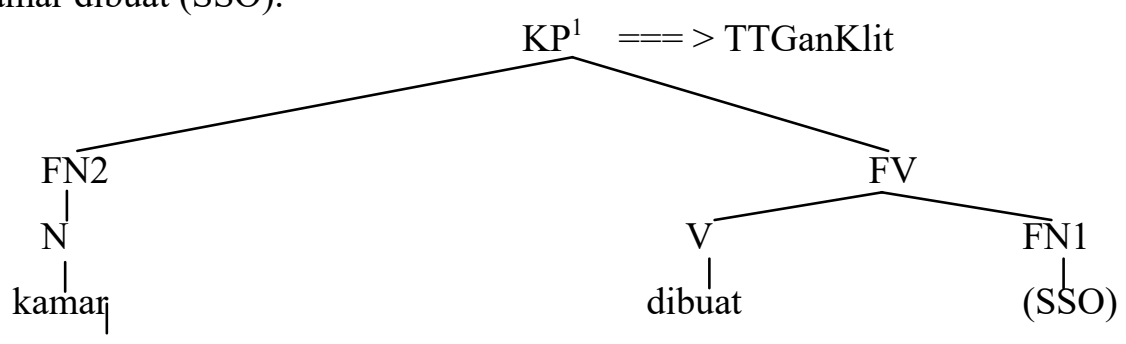


The integrating sentence that has undergone a transformation with the TTF rules then undergoes a klitika substitute transformation, re- sulting the KTTF changes into KTTGanKlit. The subtituted part is FN1, whivh is ( $\mathrm{SSO}$ ) with the klitika -nya.

$\mathrm{KP}^{2}=$ Kamar dibuatnya .

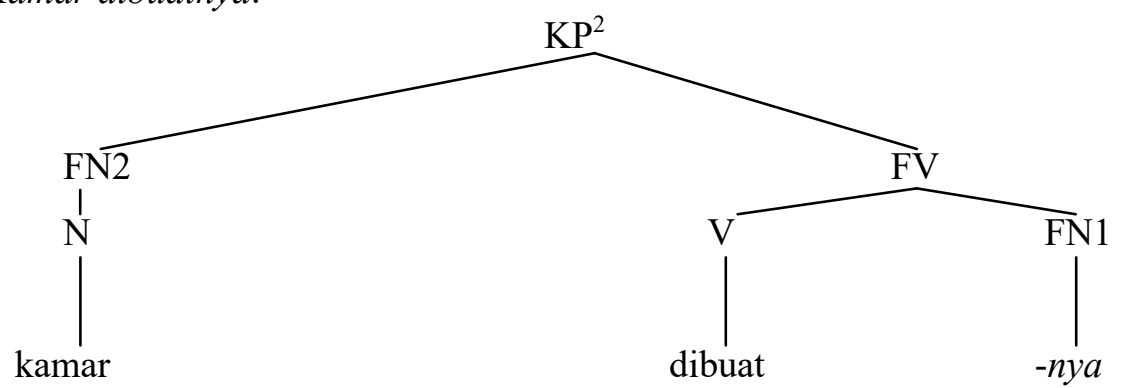

$\mathrm{KS}=$ Kamar yang dibuatnya dengan nuansa ulang tahun.

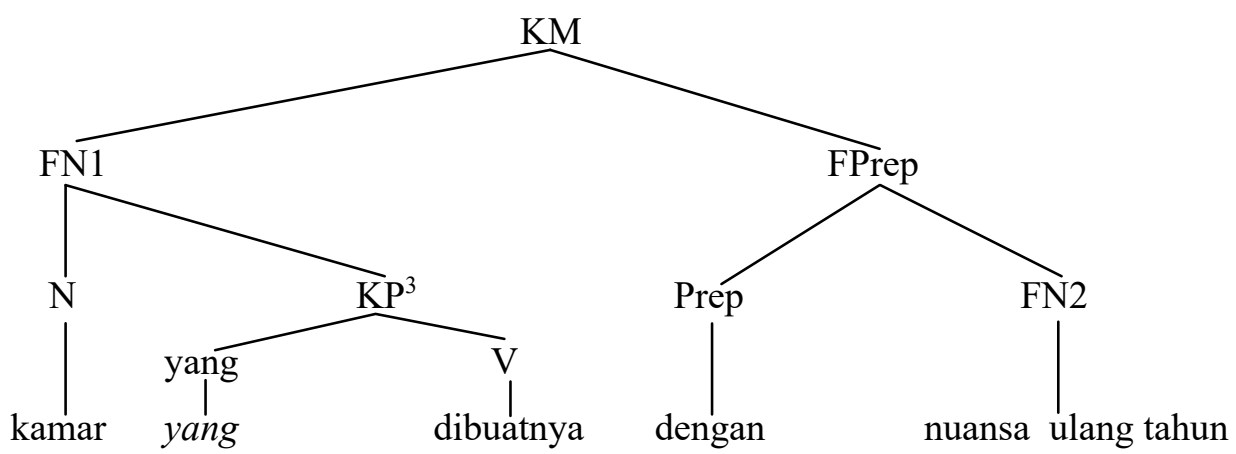

From the above example, it shows that the FN of kamar in KP changes to yang as the embedded marker of the sentence (1). The syntactic competence of spoken Bahasa Indonesia of the eighth grade students of SMPN 1 Palu is shown by the ability of students to make embedded sentences through 3 transformation processes: focused transformation, klitika subtitute transformation, and embedded transformation.

\section{FN Complement}

Based on the results of the study, the syntactic competence of spoken Bahasa Indonesia of the eighth grade students of SMPN 1 Palu, which was shown in the embedded sentence with FN complementary pattern explained in the following sentence (2).

(2) Persiapan kami sebelum dimulai lomba dua hari sebelumnya.

Sentence (2) is included in the embedded transformation sentence with the embedder of FN complement. This sentence has matrix KD2 pattern, which is Kami mempersiapkan lomba dua hari sebelumnya. The sentence has integrating sentence (SES) of memulai lomba. This integrating sentence completes the FN with persiapan kami. The following is the analysis of the SD and ST sentences.

KM: Kami mempersiapkan lomba dua hari sebelum (lomba).

$\mathrm{SD}$ (KD2): FN1 + FV + FN2 + FNum

$\mathrm{KTM}^{1}$ :Kami mempersiapkan lomba dua hari sebelumnya.

STM $^{1}$ (TTGanKlit): FN1 + FV + FN2 + FNum+Klit

$\mathrm{KTM}^{2}:$ Kami mempersiapkan dua hari sebelumnya

$\mathrm{STM}^{2}$ (TTKLesap): FN1 + FV + FNum $\mathrm{KTM}^{3}$ : Persiapan kami dua hari sebelumnya $\mathrm{STM}^{3}$ (TTNom): FN1 + FNum

KP: (SSO) memulai lomba.

$\mathrm{SD}$ (KD2): FN1 + FV + FN2

$\mathrm{KP}^{1}$ : Lomba dimulai (SSO).

$\mathrm{STP}^{1}(\mathrm{TTF}(1)): \mathrm{FN} 2+\mathrm{FV}+\mathrm{FN} 1$

$\mathrm{KP}^{2}:$ Lomba dimulai. 
$\mathrm{STP}^{2}$ (TTKLesap): FN2 + FV

$\mathrm{KP}^{3}$ : Dimulai lomba.

$\mathrm{STP}^{3}(\mathrm{TTF}(2)): \mathrm{FV}+\mathrm{FN}$

KS: Persiapan kami sebelum dimulai lomba

dua hari sebelumnya.

ST(TS): FN + sebelum + FV + FN + FNum
Description:

TTNom= Transformasi Tunggal Nominalisasi

(Nominalisation Single Transformation)

TTKLesap $=\quad$ Transformasi Tunggal

Pengurangan Pelesapan

The process of sentence (2) transformation is described in the following chart.

$\mathrm{KM}=$ Kami mempersiapkan lomba dua hari sebelum (lomba).

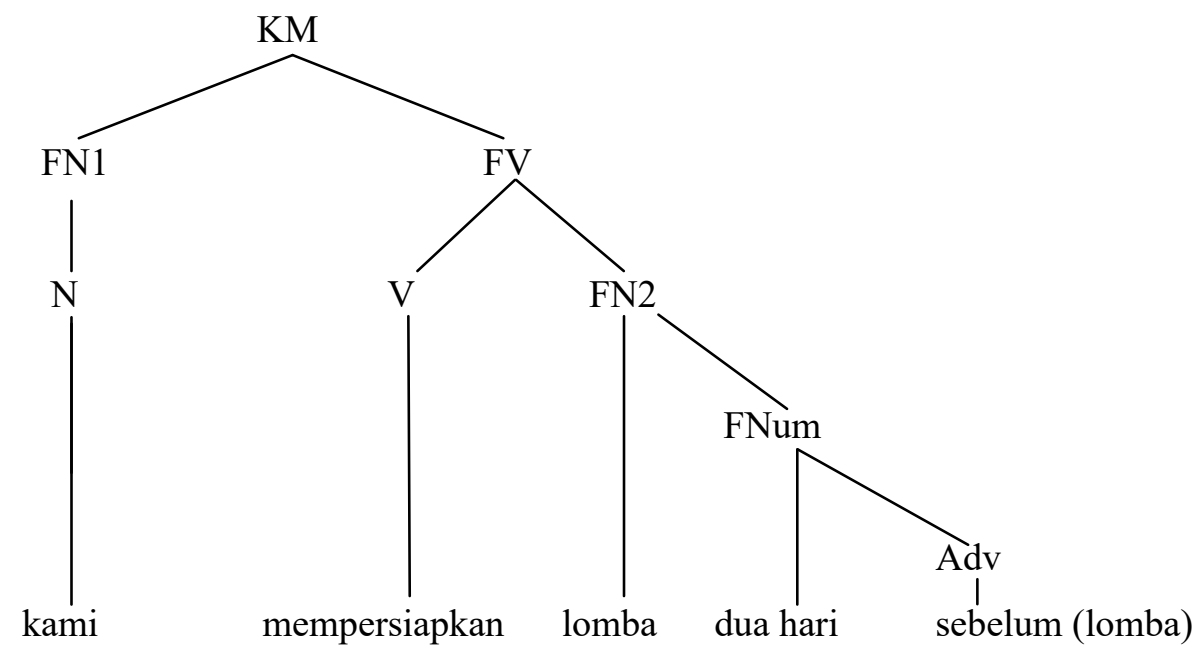

The sentence above is patterned KD2, namely $\mathrm{FN} 1+\mathrm{FV}+\mathrm{FN} 2+\mathrm{FNum}$. This KM underwent a transformation of the substitution of clitics into KTTGanKlit. The part that was replaced was the race in $\mathrm{Adv}$ before the race.

$\mathrm{KM} 1=$ We prepared the race two days before.
The matrix sentence above has the pattern of KD2, namely FN1 + FV + FN2 + FNum. This $\mathrm{KM}$ underwent a transformation of clitics substitution into KTTGanKlit. The part that was replaced is the word lomba in Adv of sebelum lomba.

$\mathrm{KM}^{1}=$ Kami mempersiapkan lomba dua hari sebelumnya.

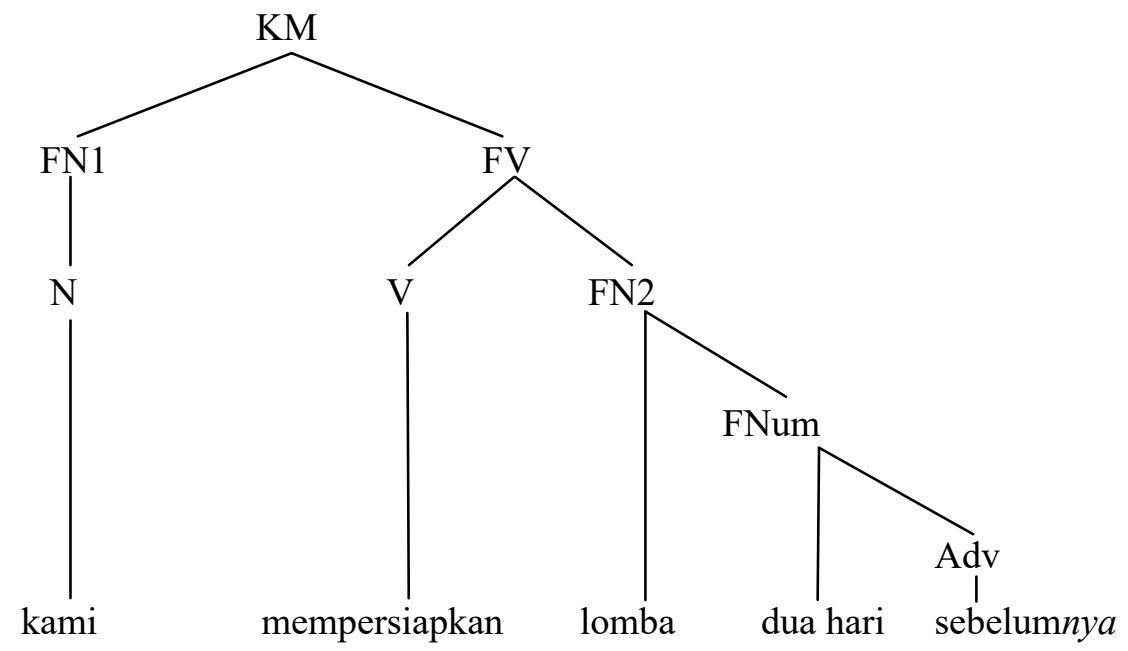

The above matrix sentence having the pattern of reduction. The part that is omitted is FN2, which KTTGanKlit underwent a transformation of is lomba. 
$\mathrm{KM}^{2}=$ Kami mempersiapkan dua hari sebelumnya.

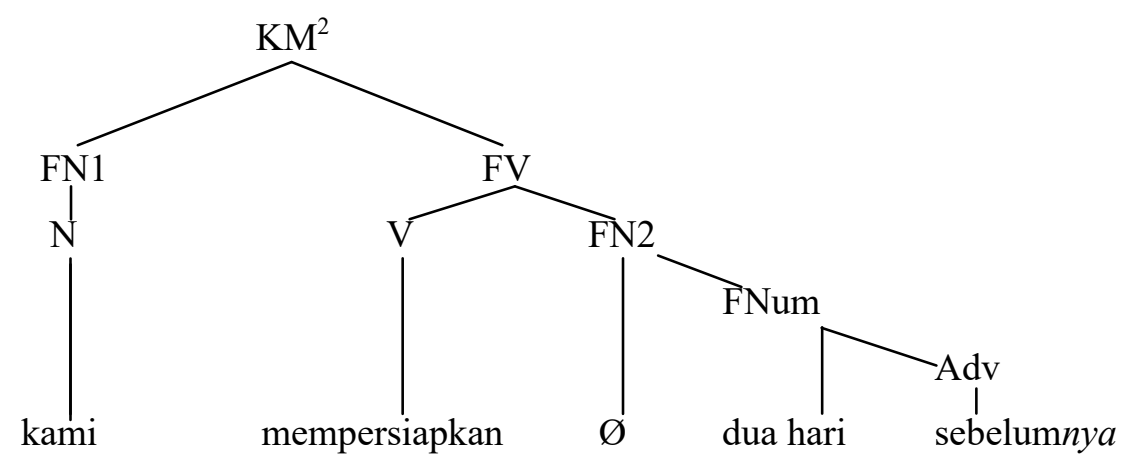

The matrix sentence with the pattern of the KTTLesap underwent a nominalization transforNotes $\varnothing=$ the reduction mation. The part nominalized is FV which had become persiapan.

$\mathrm{KM}^{3}=$ Persiapan kami dua hari sebelumnya.

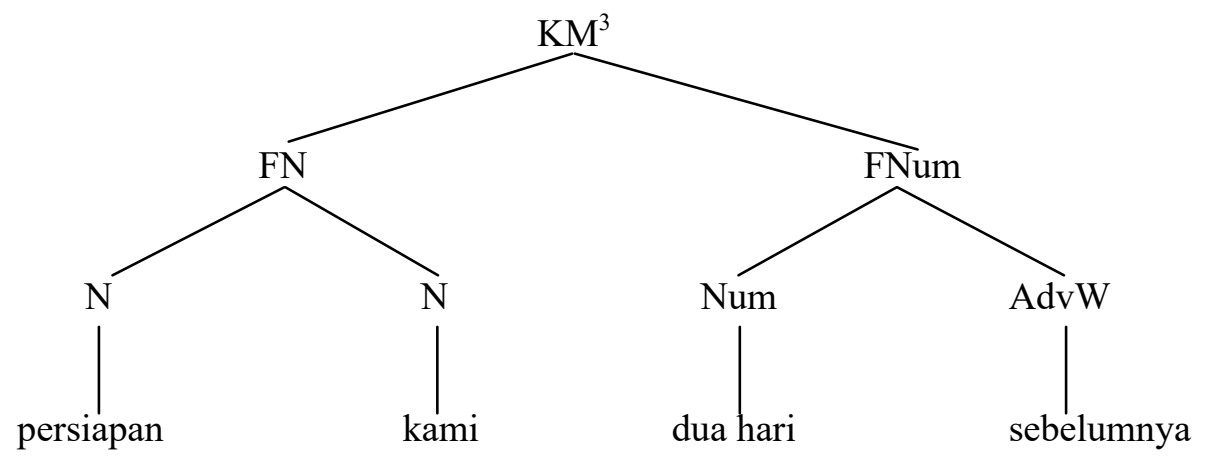

$\mathrm{KP}=(\mathrm{SSO})$ memulai lomba.

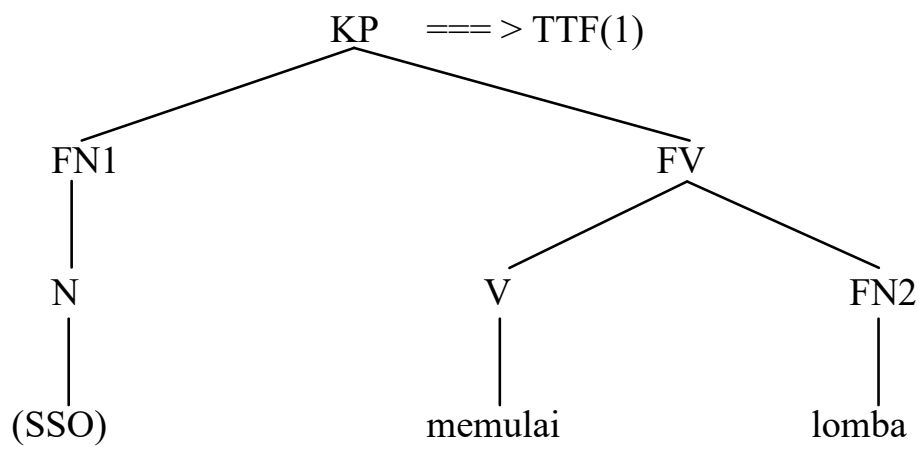

The integrating sentence above has the pattern of KD2; FN1 + FV + FN2.the KP itself experienced a single focus transformation with the pat- tern of displacement. The part that is moved is FN2 which was placed in the beginning of the sentence. 
$\mathrm{KP}^{1}=$ Lomba dimulai (SSO).

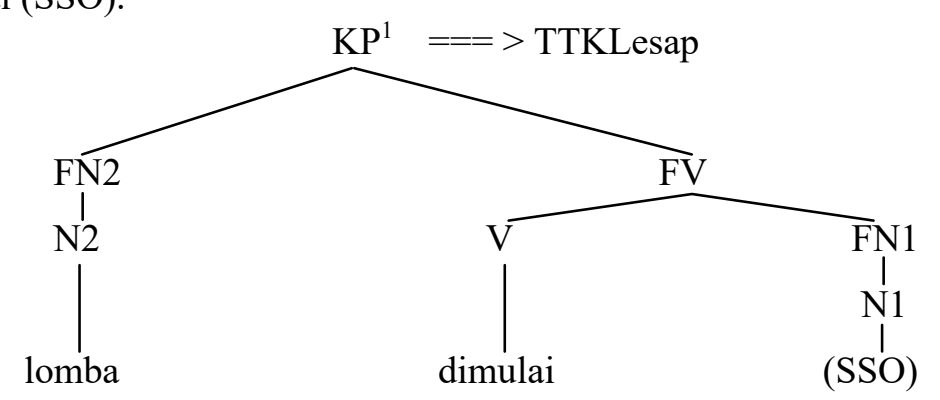

The combination patterned TTF sentence underwent a transformation of reduction. The omitted part is FN1, i.e. (SSO).

$\mathrm{KP}^{2}=$ Lomba dimulai.

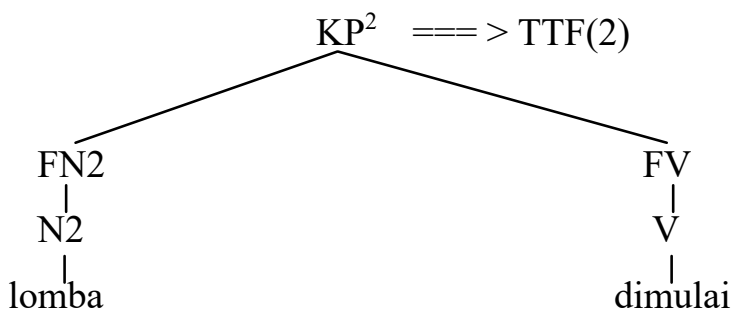

The integrating sentence having the pattern of TTK Lesap underwmt a single focus transformation with the displacement pattern. The part that is moved is FV which was placed in the beginning of the sentence. The integrating sentence of KP3 is then being attached to KM3 $\mathrm{KP}^{3}=$ Dimulai lomba

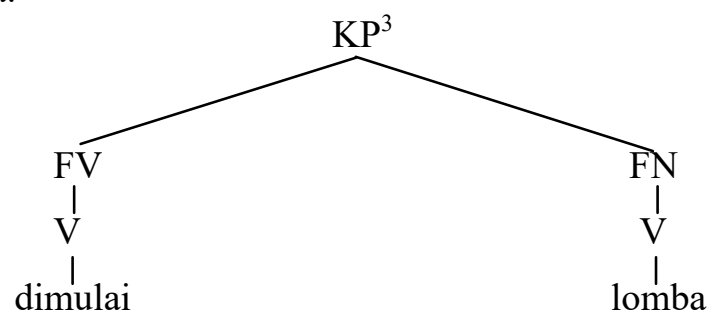

$\mathrm{KS}=$ Persiapan kami sebelum dimulai lomba dua hari sebelumnya

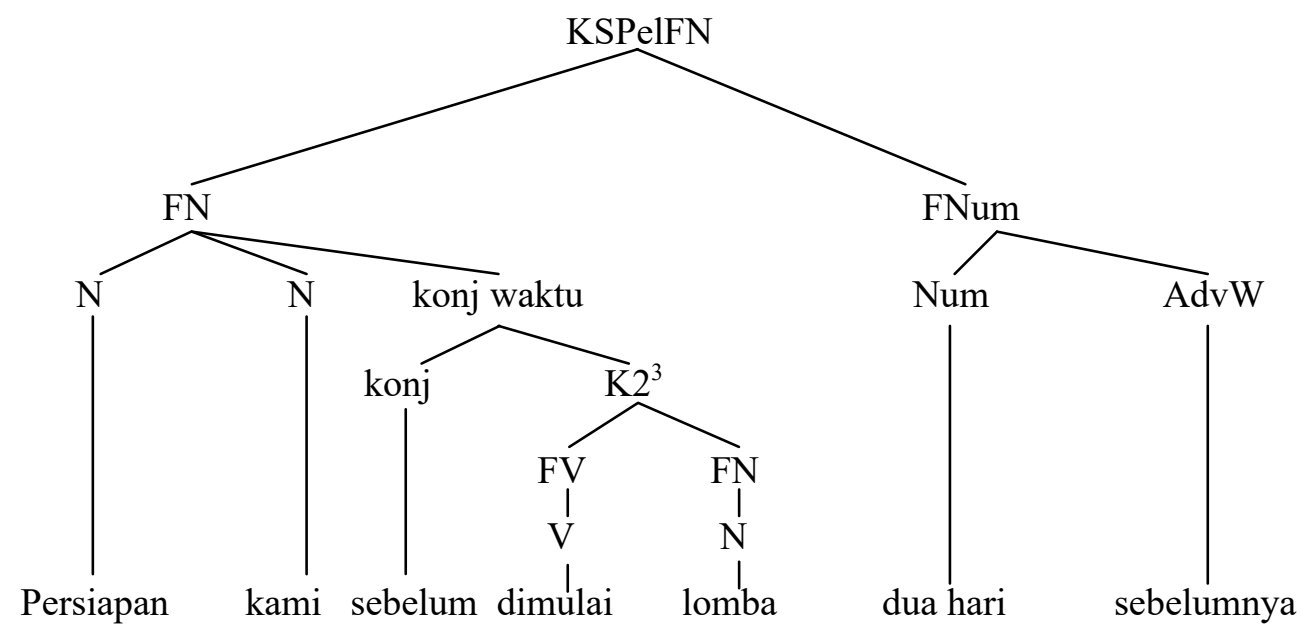


The marker attached in sentence (2) is the word sebelum. Indonesian syntactic oral competence of 8th grade students of SMPN 1 Palu was shown by the students' ability to make embedded sentences through the transformation process that took place, both on KM and KP. In $\mathrm{KM}$, there are 3 transformations; the single transformation of clitics substitution, transformation of reduction and transformation of nominalization. In another case, there are three transformations recorded in the KP; two focus transformations and transformation of reduction.

Thus, the syntactic oral competence of Indonesian at 8th grade students of SMPN 1 Palu which is manifested in the transformational sentence is shown by the use of the seven transformation rules.

\section{Complementary $\mathrm{FV}$}

Based on the results of the study, the indonesian syntactic oral competence of the 8th grade students at SMPN 1 Palu shown in thr embedded sentences was revealed to have the pattern of complementary FV. Indonesian syntactic oral competence of 8th grade students oat SMPN 1 Palu, which has a complementary FV pattern explained in the following sentence (3). Tiga besar itu diambil untuk mempresentasikan sesuatu yang berhubungan dengan sekolahnya

$\mathrm{KM}=(\mathrm{SSO})$ mengambil (juara) tiga besar itu.
Sentence (3) is considered to be embedded sentence because there are basic sentences embedded in other basic sentences. Here's the analysis of SD and ST sentences.

KM: (SSO) mengambil tiga besar itu.

$\mathrm{SD}$ (KD2): FN1 + FV + FN2

$\mathrm{KTM}^{1}$ : Tiga besar itu diambil (SSO).

STM1 (TTF): FN2 + FV + FN1

$\mathrm{KM}^{2}$ : (Juara) tiga besar itu diambil.

$\mathrm{STM}^{2}$ (TTLesap(1)): FN2 + FV

$\mathrm{KM}^{2}$ : tiga besar itu diambil.

$\mathrm{STM}^{2}$ (TTLesap(2)): FN2 + FV

KP1: (SSO) mempresentasikan sesuatu.

$\mathrm{SD}$ (KD2): FN1 + FV + FN2

$\mathrm{KP} 1^{1}$ : Mempresentasikan sesuatu.

$\mathrm{STP}^{2}$ (TTLesap): FV + FN2

KP2: Sesuatu berhubungan dengan sekolah (SSO).

$\mathrm{SD}$ (KD2): FN + FV+ FPrep

$\mathrm{KP} 2^{1}$ : Sesuatu berhubungan dengan sekolahnya

STP2 ${ }^{1}$ (TTGanKlit): FN + FV + FPrep

KS1: Mempresentasikan sesuatu yang berhubungan dengan sekolahnya

STS1 (TSA): FV + FN + yang + KP2 ${ }^{1}$

KS2: Tiga besar itu diambil untuk mempresentasikan sesuatu yang berhubungan dengan sekolahnya.

STS (TSPelFV): $\mathrm{K} 1^{2}+$ untuk $+\mathrm{K} 2^{1}+\mathrm{K} 3^{2}$

The description of transformation process took places in sentence (3) is seen the following.

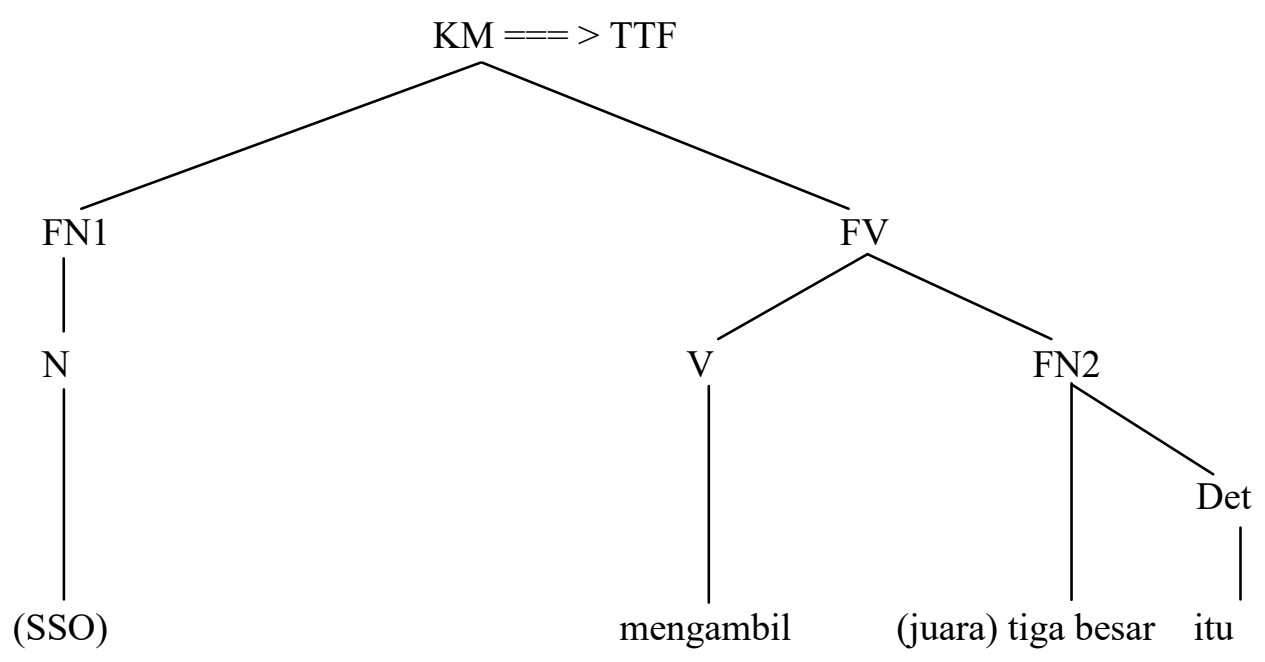

The above matrix sentence has the pattern of KD2, namely FN1 + FV + FN2. The KM itself experienced a single transformation focus with a passive structure pattern. 
$\mathrm{KM}^{1}=($ Juara$)$ tiga besar itu diambil $(\mathrm{SSO})$

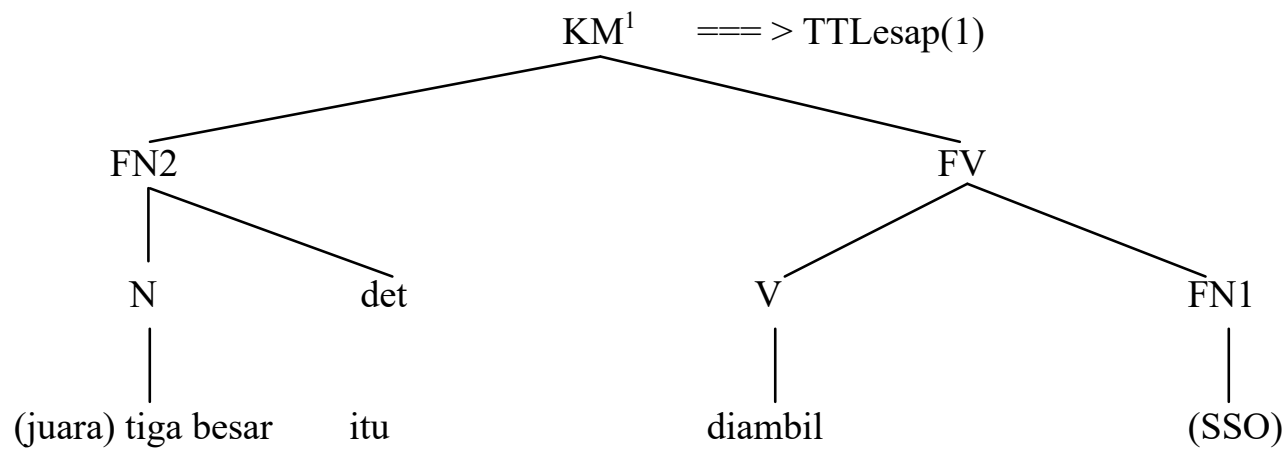

KM1 underwent a single transformation of reduction of $\mathrm{N}$ om FN2 (SOS)

$\mathrm{KM}^{2}=($ Juara $)$ tiga besar itu diambil.

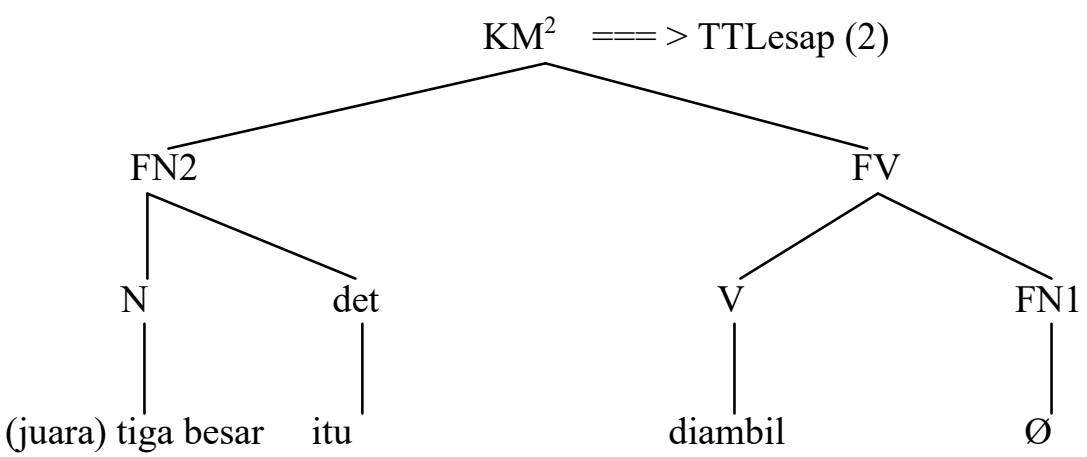

KM2 underwent a single transformation of re- goes a single transformation reducing reduction duction of $\mathrm{N}$ on FN2, i.e. (SSO). KM1 under- on FN1, i.e. (SSO).

$\mathrm{KM}^{3}=$ Tiga besar itu diambil.

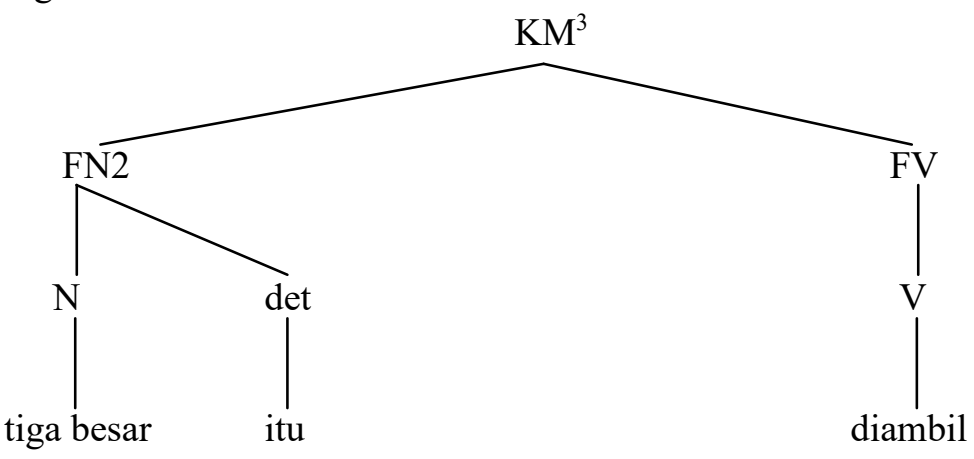

$\mathrm{KP} 1=(\mathrm{SSO})$ mempresentasikan sesuatu

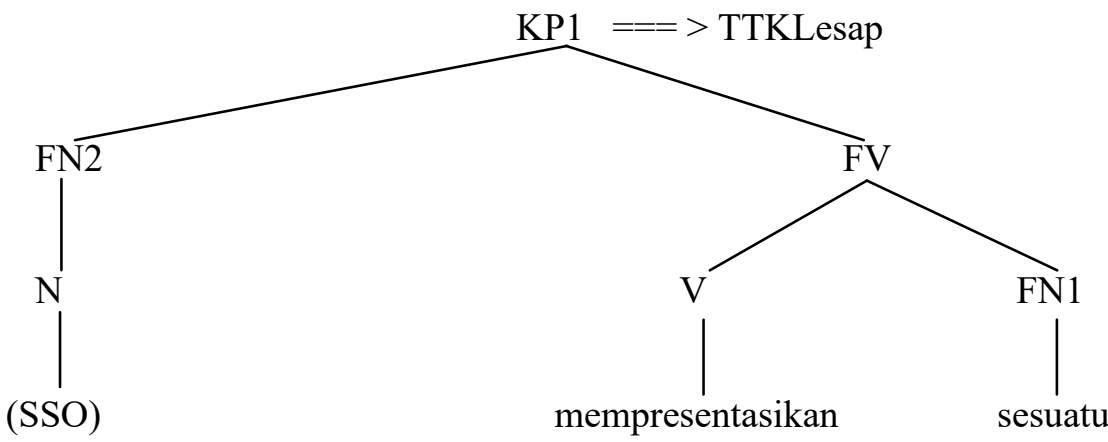


The above integrating sentence having the pattern of KD2, namely FN1 + FV + FN2. This KP1 had undergone a transformation of reduct-

$\mathrm{KP} 1^{1}=$ mempresentasikan sesuatu ion into KTTLesap. The replaced part is FN1, i.e. (SSO).

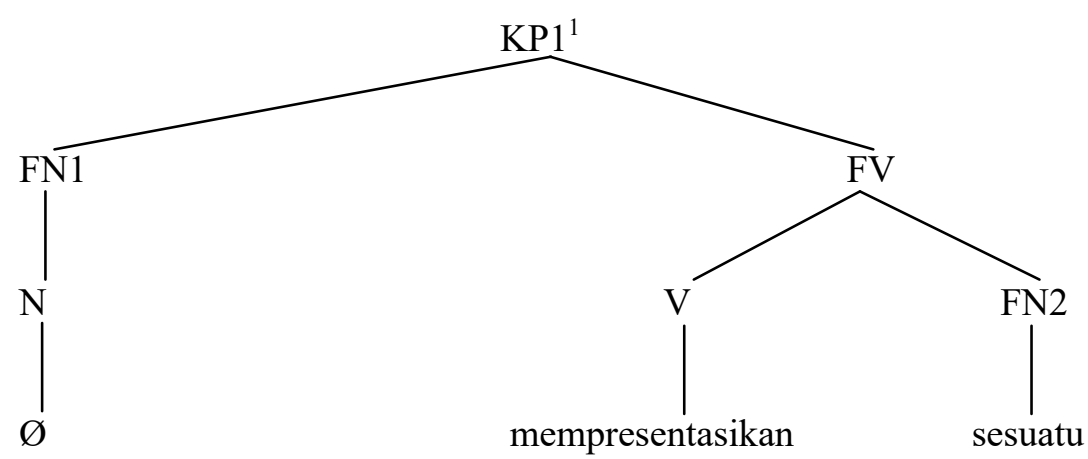

$\mathrm{KP} 2$ = sesuatu berhubungan dengan sekolah (SSO).

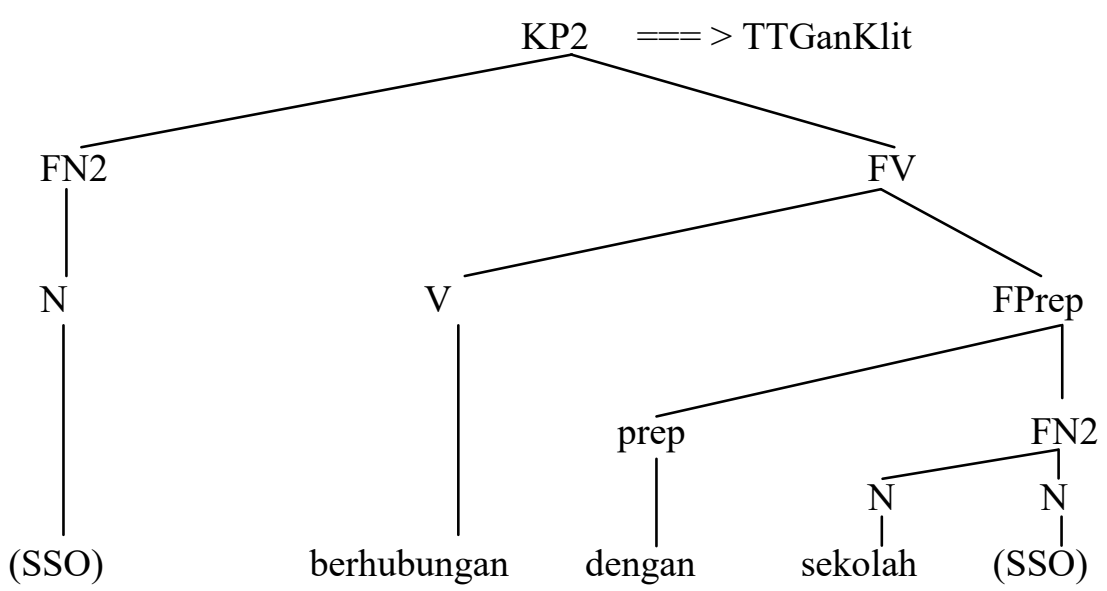

The KP1 with the pattern of KD2 underwent a TTGanKlit transformation. The part that is replaced with the clitics is FN2, that is (SSO).

$\mathrm{KP} 2^{1}=$ Sesuatu berhubungan dengan sekolahnya

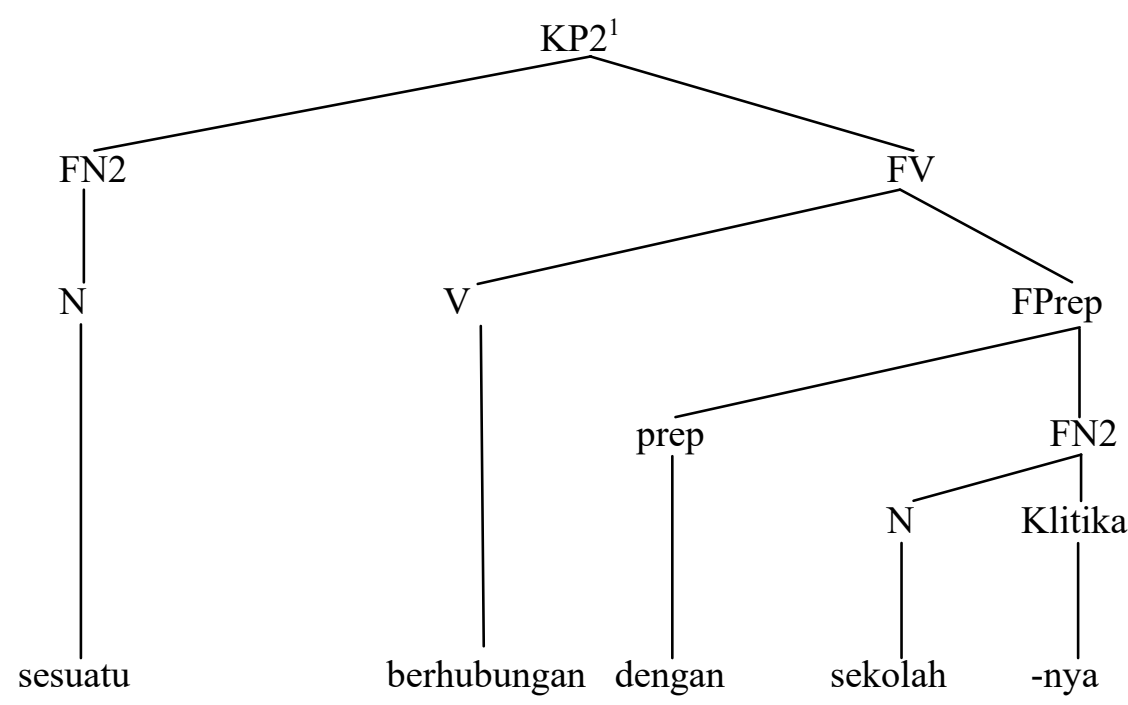


The KP $2{ }^{1}$ with the pattern of TTGanKlit is attaches into the KP $1{ }^{1}$ with a mere marker of yang.

$\mathrm{KS}=$ Mempresentasikan sesuatu yang berhubungan dengan sekolahnya.

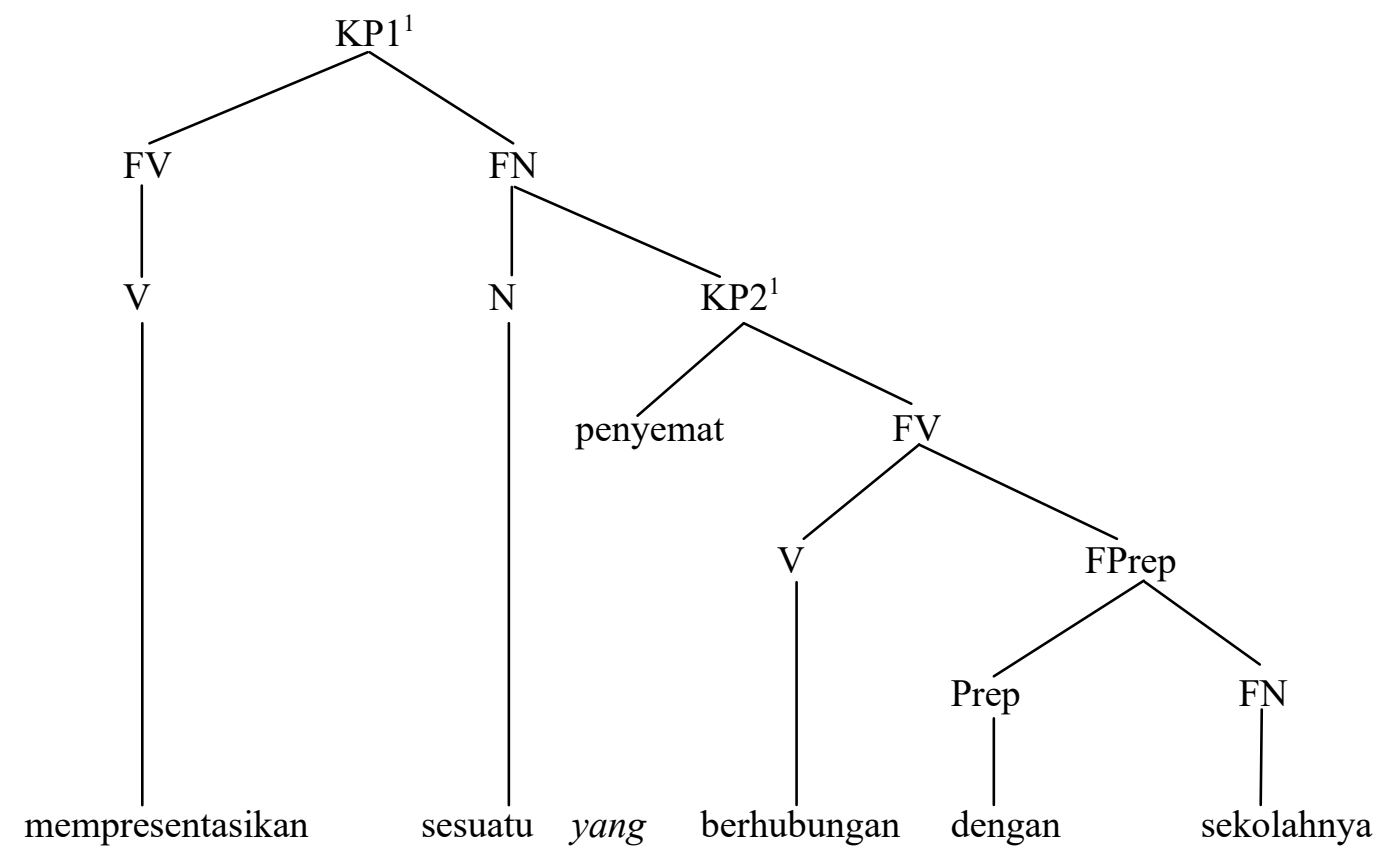

Furthermore KS1 is embedded into KM3.

$\mathrm{KS}=$ Tiga besar itu diambil untuk mempresentasikan sesuatu yang berhubungan dengan sekolahnya

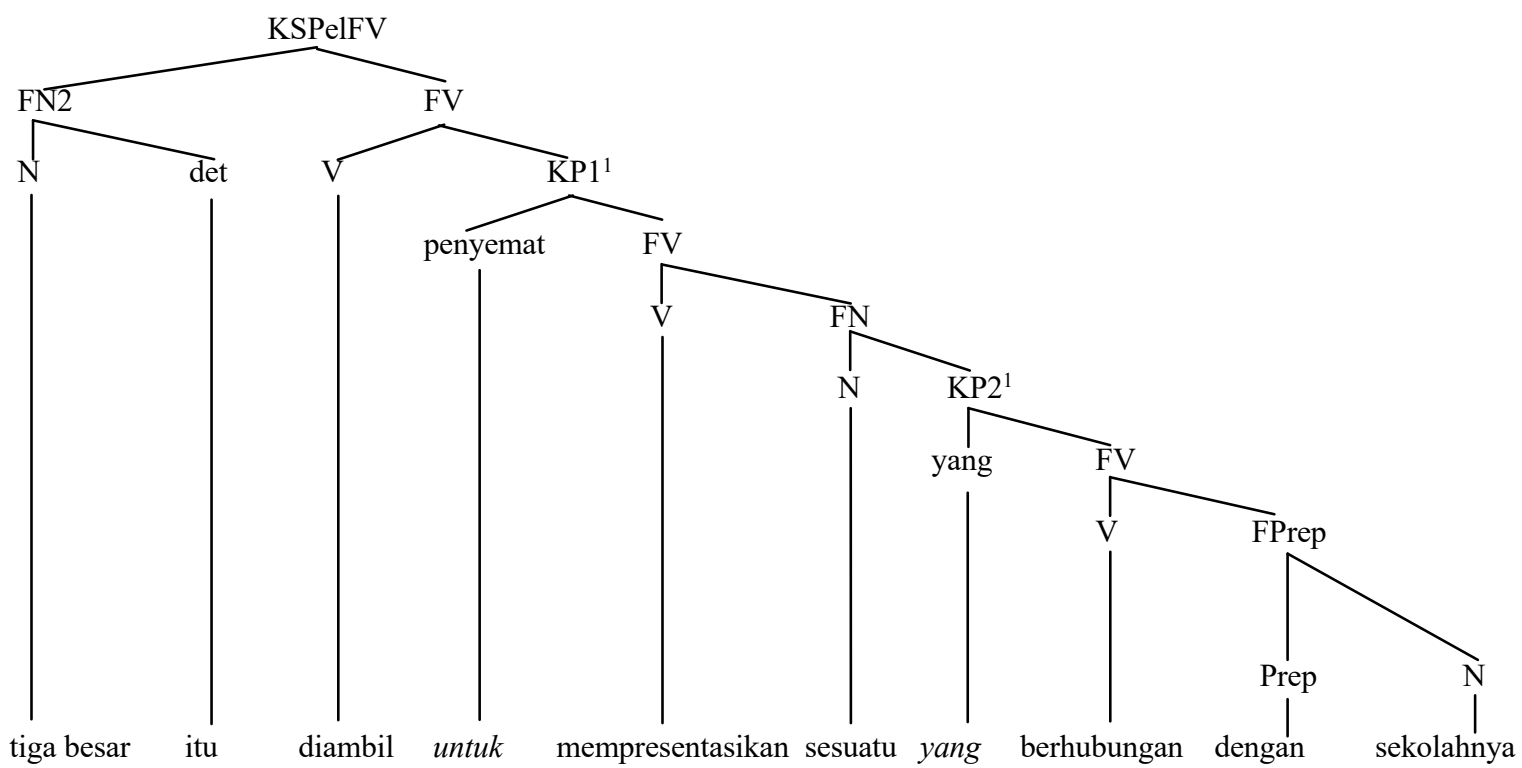

The 8th Grade of Indonesian syntactic oral competence in Palu 1 Junior High School within sentence (3) is shown by the use of seven rules of transformation. KM underwent three transformations consisting of TTF and two TTK-
Lesap. KP1 underwent a single transformation, namely TTKLesap. KP2 underwent a transformation, namely TTGanKlit. KP11 and KP21 underwent TSA transformation and the last is TS transformation. 


\section{Discussion}

The syntactic competence of spoken Indonesian 8th grade students of SMPN 1 Palu, which is manifested in the embedded sentences presented in the results section, shows that students have the competence to construct embedded sentences consisting of attributive embed sentences, complementary embed sentences of $\mathrm{FN}$, and complementary embed sentences of FV.

The syntactic competence is a competency that develops along with the development of age, cognitive, and interaction of students with the environment. During junior high school, students had grammatical awareness. Syntactic competencies have been held by students since they were in the previous level of education, namely in elementary school. Ghazali (1999) shows that elementary school students already have the ability to arrange complex sentences. Students already have syntactic competence and are able to present their ideas in complex sentences.

The finding of students 'syntactic Indonesian oral syntactic which is manifested in the embedded sentence pattern shows that the students' competence in composing sentences is carried out using several transformational principles. One of them is an embedded sentence formed using seven transformation sentence patterns. The seven patterns show that students already have the competence to compose a sentence using the patterns of transformation rules that they have mastered. The use of seven transformation patterns also shows that seven changes occur in the basic sentence before it finally becomes an embedded sentence.

The implication of the results of this study is the teacher can design language learning based on the competencies possessed by students. Syntactic competencies that are manifested in embedded sentences can be used for conversations, both formally and informally so that students can communicate effectively.

The findings of the research about the syntactic competence of the oral Indonesian 8thgrade junior high school students can be applied in the effort to provide books, both storybooks, and textbooks. Based on the syntactic competence of students embodied in the embed sentence patterns, storybooks and textbooks for 8thgrade junior high school students can be selected based on the sentence patterns that have been mastered by students in composing sentences, namely focus transformation sentence patterns, transformation patterns, sentence patterns nominal transformation, attributive embodiment transformation patterns, FN complementary embodiment sentence patterns, and FV complementary embodiment transformation sentence patterns.

Research findings of the syntactic competence of the oral Indonesian 8th-grade junior high school students can also be applied in the preparation of educational grammar. The grammar that can be arranged based on the results of this study is the rules about the formation and variety of embedded sentences. The embedded sentences are formed using attributive patterns, complementary patterns of $\mathrm{FN}$, and complementary patterns of FV. The sentence patterns are used in interactions between the teacher and students, between students, and between students and people in the school environment.

The findings of this study cannot be separated from context because they are taken from sources in the form of spoken language. The teacher can consider the differences and similarities between the characteristics of spoken and written languages in learning. Teachers can use the results of this study to optimize students' communicative competence. The grammatical features of spoken language should be taken into consideration in language learning. In the language learning process, the teacher should be a guide and facilitator who can make it easier for students to communicate. The syntactic competence of spoken Indonesian 8th grade junior high school students embodied in the embedded sentences can be developed to meet the needs of logical and abstract thinking.

\section{CONCLUSION}

Syntactic transformational competencies in the embedded sentence of spoken Indonesian language at junior high school can be summaryzed below.

First, the transformational attributive embedded sentence is attributive. TSA is marked by the use of yang. The marker of yang is attached to the FN. The part is preceded by the statement or attribute of the FN. KM at KSA has a KD5 pattern. KP pattern on KSA had the undergone a transformation before being embedded on KM. 
Secondly, FN's complementary transformation sentence. KSPel FN is marked by the KP's attachment with the marker of sebelum. Parts of the sentence marked by sebelum turned into complementary FN. KM on KSPel FN has a KD2 pattern.KM pattern underwebt a transformation before being embedded by KP. Similarly, the KP on KSPel FN had undergone a transformation before being attached to KM.

Third, the complementary transformational embeddedl sentence FV. The KSPel FV is

\section{REFERENCES}

Cain, K. (2007). Syntactic awareness and reading ability: Is there any evidence for a special relationship. Applied Psycholinguistics, 28(4), 679-694, doi:http://dx.doi.org/10.1017/ S0142716407070361.

Chomsky, N. (1965). Aspect of theory of syntax. Cambridge: The MIT Press.

del Castillo. (2016). Identifying linguistic competence what linguistic competence consists. Education and Linguistics Reseacrh, 2(1), 120-141.

Ghazali, A. S. (1999). Kerumitan kalimat bahasa Indonesia siswa sekolah dasar. Dissertation. Malang: Program Pascasarjana Universitas Negeri Malang.

Lapoliwa, H. (1990). Klausa pemerlengkapan dalam bahasa Indonesia. Yogyakarta: Kanisius.

Miles, M. B. dan Huberman, A. M. (1984). Qualitative data analysis: A source book for new methods. Beverly Hills CA: Sage Publication Inc

Rahmalia, I. (2016). Student's linguistic competence in essay writing. Al-Ta'lim, 23(3), 241-248.

Samsuri. (1985). Tata kalimat bahasa Indonesia. Malang: Sastra Hudaya. marked by the word untuk. The sentence section marked by the word untuk had become a complementary FV. KM on KSPel FV has a KD2 pattern. KM pattern underwent transformation before being embedded into KP. KP underwnet transformation before being embedded into KM. KM on KSPel FV consists of two KPs. The process of embedding on KSPel FV occurs gradually. KP2 is embedded on KP1 with the TSA rules, then the results of the two KP embeds are embedded on KM.

Samsuri (1991). Analisis berbahasa. Jakarta: Erlangga.

Samsuri. (1994). Analisis kalimat. Jakarta: Erlangga.

Shofiyuddin. (2017). Transformasi sematan klausa relatif pada teks terjemahan Al Qur'an yang mengandung etika berbahasa. Jurnal Pendidikan Bahasa dan Sastra, 7(2), 221-231, doi: http://dx.doi.org/10.17509/bs_jpbsp.v17i29660 .

Suhardi. (2009). Klausa komplemen dalam kalimat transformasi sematan. Jurnal Diksi, 16(1), 8795.

Suparno. (1993). Konstruksi tema rema dalam bahasa Indonesia lisan tidak resmi masyarakat kotamadya Malang. Jakarta: Pusat Pembinaan dan Pengembangan Bahasa

Suwarno. (2017). The important of oral performance: What makes a successful proficiency-based foreign language program. Journal of Intensive Studies on Language, Literature, Art, and Culture, 1(1), 1-18.

Wahyuni, D. et al. (2014). Linguistic competence and speaking performance of English education study program student of Sriwijaya University. The Journal of English Literacy Education, 1(2), 83-92. 